\title{
Liquid-Liquid Extraction-Spectrophotometric Investigations of Three Ternary Complexes of $\operatorname{Vanadium}(\mathrm{V})$
}

\author{
Kiril B. Gavazov* and Teodora S. Stefanova \\ Department of General and Inorganic Chemistry, University of Plovdiv "Paissii Hilendarski", 4000, Plovdiv, Bulgaria
}

RECEIVED FEBRUARY 20, 2014; REVISED MAY 23, 2014; ACCEPTED JULY 15, 2014

\begin{abstract}
Complex formation and liquid-liquid extraction (LLE) were studied in systems containing vana$\operatorname{dium}(\mathrm{V})$, 5-methyl-4-(2-thiazolylazo)resorcinol (TAO), tetrazolium salt (TZS), water and chloroform. The following three TZSs were used: 3-(4,5-dimethyl-2-thiazol)-2,5-diphenyl-2H-tetrazolium bromide (MTT), 3-(2-naphtyl)-2,5-diphenyl-2H-tetrazolium chloride (Tetrazolium violet, TV), and 2-(4-iodophenyl)-3-(4nitrophenyl)-5-phenyl-2H-tetrazolium chloride (INT). Concentration of the reagents (TAO and TZS), $\mathrm{pH}$ of the aqueous medium, and shaking time were subjects of optimization experiments. Formation of ternary complexes with a composition of 2:2:2 was demonstrated by a set of different methods. Some key characteristics concerning the analytical application of the studied LLE-chromogenic systems were established as well.
\end{abstract}

Keywords: solvent extraction, 4-(2-thiazolylazo)orcinol, tetrazolium salt, ion-association, 2:2:2 complex

\section{INTRODUCTION}

The azo compound 4-(2-thiazolylazo)orcinol \{TAO; 5methyl-4-(2-thiazolylazo)resorcinol $\}$ was synthesized in 1960 by Jensen. ${ }^{1}$ He showed its applicability for complexometric titration of metal ions $\{$ e.g. $\mathrm{Cu}(\mathrm{II})$, $\mathrm{Co}(\mathrm{III}), \mathrm{Ni}(\mathrm{II}), \mathrm{Mg}(\mathrm{II}), \mathrm{Ca}(\mathrm{II}), \mathrm{Mn}(\mathrm{II})$, and $\mathrm{Cd}(\mathrm{II})\}$ and noted the formation of colored species with $\mathrm{Th}(\mathrm{IV})$, $\mathrm{La}(\mathrm{III}), \mathrm{U}(\mathrm{VI}), \mathrm{Hg}(\mathrm{II}), \mathrm{Pb}(\mathrm{II}), \mathrm{Zn}(\mathrm{II})$ and $\mathrm{Zr}(\mathrm{IV})$. In the 1970-1980s the list of metal ions which form colored complexes with TAO was enriched with $\mathrm{V}(\mathrm{V}),{ }^{2} \mathrm{Co}(\mathrm{II})^{3}$ and $\mathrm{Fe}(\mathrm{II}) .{ }^{4}$ Since many azo dyes were examined in the mentioned works ${ }^{1-4}$ and TAO turned out to be less sensitive colorimetric reagent than other of the suggested compounds, ${ }^{1-7}$ its analytical potential remained unexploited for 2-3 decades. It was not until the beginning of the new millennium, that some analytical applications of TAO appeared, namely determination of cobalt, ${ }^{8}$ cadmium, ${ }^{9}$ titanium, ${ }^{9,10}$ gold, palladium and lead, ${ }^{11}$ copper and nickel, ${ }^{12}$ and cadmium and lead. ${ }^{13}$ The separation/preconcentration techniques used in these applications were chromatography, ${ }^{8,9}$ sorption onto activated carbon, ${ }^{9,10}$ coprecipitation, ${ }^{11}$ solid phase extraction, ${ }^{12}$ and cloud-point extraction. ${ }^{13}$

TAO was characterized in Ref. 13 as "a very stable and fairly selective complexing reagent". One can expect that this reagent is better for liquid-liquid extraction (LLE) separation/preconcentration based on ion- association systems ${ }^{14}$ than the well-known 4-(2-thiazolylazo)resorcinol (TAR) ${ }^{5,7}$ and 4-(2-pyridylazo)resorcinol (PAR) ${ }^{15,16}$ by virtue of the additional $\mathrm{CH}_{3}$ group in its molecule (Table 1). However, the LLE behavior of TAO has never been studied. The only work which has touched the problems related to LLE (i.e. determination of the LLE distribution ratio of TAO in acetonitrilewater/n-octane extraction system) was devoted to the retention behavior in reversed phase liquid chromatography. ${ }^{17}$

The objectives of this work were to investigate three LLE systems containing vanadium(V), TAO, tetrazolium salt (TZS; see Table 1), water and chloroform. TZSs are cationic ion-association reagents ${ }^{18}$ with resent applications for LLE separation ${ }^{19}$ and spectrophotometric determination of metal and nonmetal ions. ${ }^{20-23}$ LLE systems involving PAR-TZS or TAR-TZS were systematically investigated in our laboratory and some of these systems were applied for $\mathrm{V}(\mathrm{V})$ determination ${ }^{24}$ and $\mathrm{V}(\mathrm{IV}) / \mathrm{V}(\mathrm{V})$ speciation. ${ }^{25-27}$

\section{EXPERIMENTAL}

\section{Reagents and Apparatus}

- $\mathrm{NH}_{4} \mathrm{VO}_{3}$ (puriss. p.a., VEB Laborchemie Apolda) dissolved in doubly distilled water, $2 \times 10^{-4} \mathrm{~mol} \mathrm{~L}^{-1}$.

\footnotetext{
* Author to whom correspondence should be addressed. (E-mail: kgavazov@abv.bg)
} 
Table 1. Reagents used in the present study

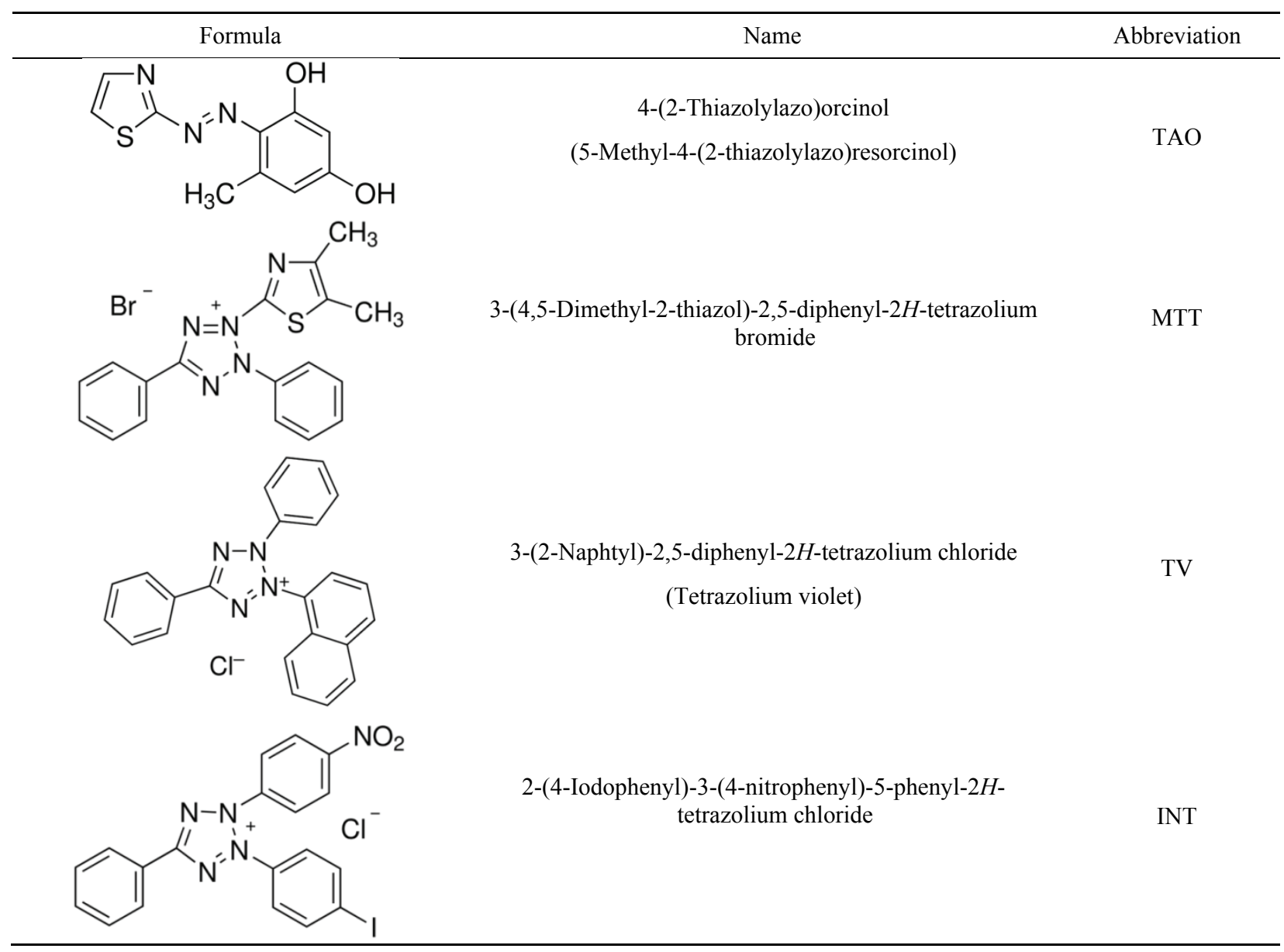

- $\operatorname{TAO}(95 \%$, Sigma-Aldrich Chemie GmbH) dissolved in slightly alkalized $(\mathrm{KOH})$ distilled water, $3 \times 10^{-3} \mathrm{~mol} \mathrm{~L}^{-1}$.

- TZSs: MTT (p.a., Loba Feinchemie), TV (p.a., Loba Feinchemie) and INT (p.a., Fluka AG), $3 \times 10^{-3} \mathrm{~mol} \mathrm{~L}^{-1}$ aqueous solutions.

- Chloroform (p.a.), additionally distilled.

- Acetate buffer solution prepared from $2 \mathrm{~mol} \mathrm{~L}^{-1}$ aqueous solutions of $\mathrm{CH}_{3} \mathrm{COOH}$ and $\mathrm{NH}_{4} \mathrm{OH}$. The resulting $\mathrm{pH}$ was checked by $\mathrm{HI}-83140 \mathrm{pH}$ meter.

- A Camspec M508 spectrophotometer (United Kingdom), equipped with $10 \mathrm{~mm}$ path-length cells.

\section{General Procedure}

Aliquots of $\mathrm{V}(\mathrm{V})$ solution, TAO solution (up to 2.7 $\mathrm{mL}$ ), buffer solution (1-3 $\mathrm{mL} ; \mathrm{pH}$ ranging from 3.2 to 7.3) and TZS solution (up to $1.7 \mathrm{~mL}$ ) were pipetted into $100 \mathrm{~mL}$ separatory funnels. The volumes were made up to $10 \mathrm{~mL}$ with distilled water. Then $10 \mathrm{~mL}$ of chloroform were added. The funnels were closed with stoppers and shaken for a fixed time (up to $6.0 \mathrm{~min}$ ). After separation of the layers, portions of the chloroform extracts were transferred through filter papers into cells. The absorbance was read against simultaneously prepared blank sample (TAO-buffer-TZS) or chloroform.

\section{Procedure for Determining the Distribution Coeffi- cients}

The distribution coefficients $D=\Sigma c\left(\mathrm{~V}(\mathrm{~V})_{\mathrm{org}}\right) /$ $\Sigma c\left(\mathrm{~V}(\mathrm{~V})_{\mathrm{aq}}\right)$ were found from the ratio $D=A_{1} /\left(A_{3}-A_{1}\right)$, where $A_{1}$ and $A_{3}$ are the absorbances (measured against blanks), obtained after a single and triple extraction, respectively. The single extraction and the first stage of the triple extraction were performed with $10 \mathrm{~mL}$ chloroform under the optimum extraction-spectrophotometric conditions (Table 2). The organic layers were transferred into $25-\mathrm{mL}$ calibrated flasks and the flask for the single extraction was brought to volume with chloroform. The second stage of the triple extraction was performed by adding a 7-mL portion of chloroform to the aqueous phase, which remained after the first stage. The third stage was performed in the same manner. The two successive organic layers were transferred to the flask containing the organic layer obtained after the first stage. The volume was brought to the mark with chloroform and shaken for homogenization. 
Table 2. Optimum operating conditions

\begin{tabular}{|c|c|c|c|c|c|}
\hline System & $\lambda_{\max } / \mathrm{nm}$ & $\mathrm{pH}$ & $c(\mathrm{TAO}) / \mathrm{mol} \mathrm{L}^{-1}$ & $c(\mathrm{TZS}) / \mathrm{mol} \mathrm{L}^{-1}$ & Extraction time / min \\
\hline $\mathrm{V}(\mathrm{V})-\mathrm{TAO}-\mathrm{H}_{2} \mathrm{O}-$ ethanol $^{(\mathrm{a})}$ & 540 & $5.0-5.5$ & No data & - & - \\
\hline $\mathrm{V}(\mathrm{V})$-TAO-MTT- $\mathrm{H}_{2} \mathrm{O}$-chloroform ${ }^{(\mathrm{b})}$ & 545 & $4.9-5.6$ & $4.5 \times 10^{-4}$ & $3.9 \times 10^{-4}$ & $3-4$ \\
\hline $\mathrm{V}(\mathrm{V})-\mathrm{TAO}-\mathrm{TV}-\mathrm{H}_{2} \mathrm{O}$-chloroform ${ }^{(\mathrm{b})}$ & 545 & $4.9-5.6$ & $3.0 \times 10^{-4}$ & $3.9 \times 10^{-4}$ & $3-4$ \\
\hline V(V)-TAO-INT-H ${ }_{2} \mathrm{O}$-chloroform ${ }^{(\mathrm{b})}$ & 544 & $5.1-5.6$ & $3.0 \times 10^{-4}$ & $4.0-5.0 \times 10^{-4}$ & $1.5-2.5$ \\
\hline
\end{tabular}

(a) According to Ref. 2.

(b) The optimization experiments were carried out at room temperature of $\approx 22^{\circ} \mathrm{C}$.

\section{RESULTS AND DISCUSSION}

\section{Optimum Conditions and Spectral Characteristics}

It is known that TAO reacts with $\mathrm{V}(\mathrm{V})$ in a slightly acidic medium $\left(\mathrm{pH}_{\mathrm{opt}}\right.$ 5.0-5.5) to form a red-colored complex with $\lambda_{\max }=540 \mathrm{~nm}$ and $\varepsilon=1.3 \times 10^{4} \mathrm{~L} \mathrm{~mol}^{-1}$ $\mathrm{cm}^{-1}$. This information, along with our experience with the extraction systems V(V)-PAR-TZS- $\mathrm{H}_{2} \mathrm{O}$-chloroform $^{27}$ and $\mathrm{V}^{\mathrm{V}}$-TAR-TZS- $\mathrm{H}_{2} \mathrm{O}$-chloroform, ${ }^{24}$ gave us a hint that well chloroform-extractable ternary ionassociation complexes can be formed at mixing $\mathrm{V}(\mathrm{V})$, TAO and TZS. The preliminary investigations and subsequent optimization experiments confirmed our expectations. They also showed that the molar absorptivity of the ternary complexes in chloroform can be 45-65\% higher than that of the binary $\mathrm{V}(\mathrm{V})-\mathrm{TAO}$ complex, ${ }^{2}$ depending on the nature of the TZS used.

Recorded spectra of the extracted at the optimum conditions (Table 2) ternary complexes are shown in Figure 1. One can judge that TV (curve $2 ; \varepsilon_{\max }=$ $2.14 \times 10^{4} \mathrm{~L} \mathrm{~mol}^{-1} \mathrm{~cm}^{-1}$ ) and MTT (curve 1; $\varepsilon_{\max }=$

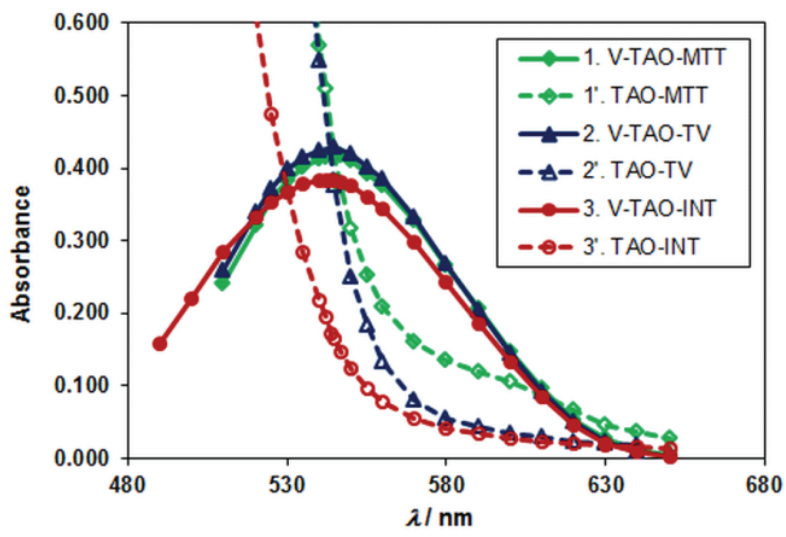

Figure 1. Absorption spectra of the ternary complexes (curves $1-3 ; c(\mathrm{~V}(\mathrm{~V}))=2 \times 10^{-5} \mathrm{~mol} \mathrm{~L}^{-1}$ ) and blank samples (curves $1^{\prime}-3$ ') in chloroform at the optimum conditions. (1,1') $c(\mathrm{TAO})=4.5 \times 10^{-4} \mathrm{~mol} \mathrm{~L}^{-1}, c(\mathrm{MTT})=3.9 \times 10^{-4} \mathrm{~mol} \mathrm{~L}^{-1}, \mathrm{pH}$ $=5.2 ;\left(2,2^{\prime}\right) c(\mathrm{TAO})=3.0 \times 10^{-4} \mathrm{~mol} \mathrm{~L}^{-1}, c(\mathrm{TV})=3.9 \times 10^{-4}$ $\mathrm{mol} \mathrm{L}{ }^{-1}, \mathrm{pH}=5.2 ;\left(3,3^{\prime}\right) c(\mathrm{TAO})=3.0 \times 10^{-4} \mathrm{~mol} \mathrm{~L}^{-1}, c(\mathrm{INT})$ $=4.0 \times 10^{-4} \mathrm{~mol} \mathrm{~L}^{-1}, \mathrm{pH}=5.5$.
$2.09 \times 10^{4} \mathrm{~L} \mathrm{~mol}^{-1} \mathrm{~cm}^{-1}$ ) ensure higher molar absorptivity than INT (curve $3 ; \varepsilon_{\max }=1.92 \times 10^{4} \mathrm{~L} \mathrm{~mol}^{-1} \mathrm{~cm}^{-1}$ ). The maximum of V(V)-TAO-INT was recorded at 544 $\mathrm{nm}$; it is shifted to $4 \mathrm{~nm}$ as compared to the maximum of the binary $\mathrm{V}(\mathrm{V})$-TAO complex. ${ }^{2}$ The maxima of the $\mathrm{V}(\mathrm{V})$-TAO-MTT and V(V)-TAO-TV were located at $\lambda$ $=545 \mathrm{~nm}$. The small difference $(1 \mathrm{~nm})$ between the absorption maxima of V(V)-TAO-INT and the other two complexes can be attributed to the more significant influence of the blank samples with MTT and TV (curves 1' and 2') on the resulting absorbance ( $\Delta A=$ $\left.A_{\mathrm{V}(\mathrm{V}) \text {-TAO-TZS }}-A_{\text {TAO-TZS }}\right)$. Our observations and the literature concerning the ion-pair formation in the systems TAR-TZS- $\mathrm{H}_{2} \mathrm{O}$-chloroform and PAR-TZS- $\mathrm{H}_{2} \mathrm{O}$ chloroform $^{28}$ indicate that the TAO-TZS blank samples (spectral curves 1'-3') most probably contain species which could be represented with the general formula $\left(\mathrm{TZ}^{+}\right)\left(\mathrm{HTAO}^{-}\right)$, where $\mathrm{HTAO}^{-}$is the monoprotonated form of TAO $=\mathrm{H}_{2}$ TAO. The expected ${ }^{18,28}$ higher stability of $\left(\mathrm{MTT}^{+}\right)\left(\mathrm{HTAO}^{-}\right) \quad\left(\lambda_{\max }=410 \mathrm{~nm}\right)$ and $\left(\mathrm{TV}^{+}\right)\left(\mathrm{HTAO}^{-}\right)\left(\lambda_{\max }=415 \mathrm{~nm}\right)$ in comparison to the stability of $\left(\mathrm{INT}^{+}\right)\left(\mathrm{HTAO}^{-}\right)\left(\lambda_{\max }=412 \mathrm{~nm}\right)$ was in

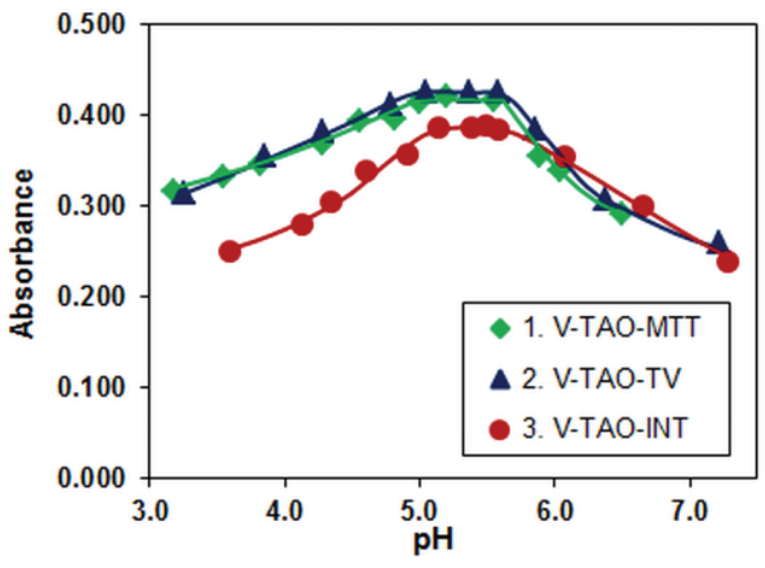

Figure 2. Absorbance of $\mathrm{V}(\mathrm{V})-\mathrm{TAO}-\mathrm{TZS}$ complexes $v s$. $\mathrm{pH}$. $(1-3) c(\mathrm{~V}(\mathrm{~V}))=2.0 \times 10^{-5} \mathrm{~mol} \mathrm{~L}^{-1} ;(1) c(\mathrm{TAO})=4.5 \times 10^{-4} \mathrm{~mol}$ $\mathrm{L}^{-1}, c(\mathrm{MTT})=3.9 \times 10^{-4} \mathrm{~mol} \mathrm{~L}^{-1} ;(2) c(\mathrm{TAO})=4.5 \times 10^{-4} \mathrm{~mol}$ $\mathrm{L}^{-1}, c(\mathrm{TV})=3.9 \times 10^{-4} \mathrm{~mol} \mathrm{~L}^{-1}$; (3) $c(\mathrm{TAO})=3.0 \times 10^{-4} \mathrm{~mol}$ $\mathrm{L}^{-1}, c(\mathrm{INT})=4.0 \times 10^{-4} \mathrm{~mol} \mathrm{~L}^{-1}$. 

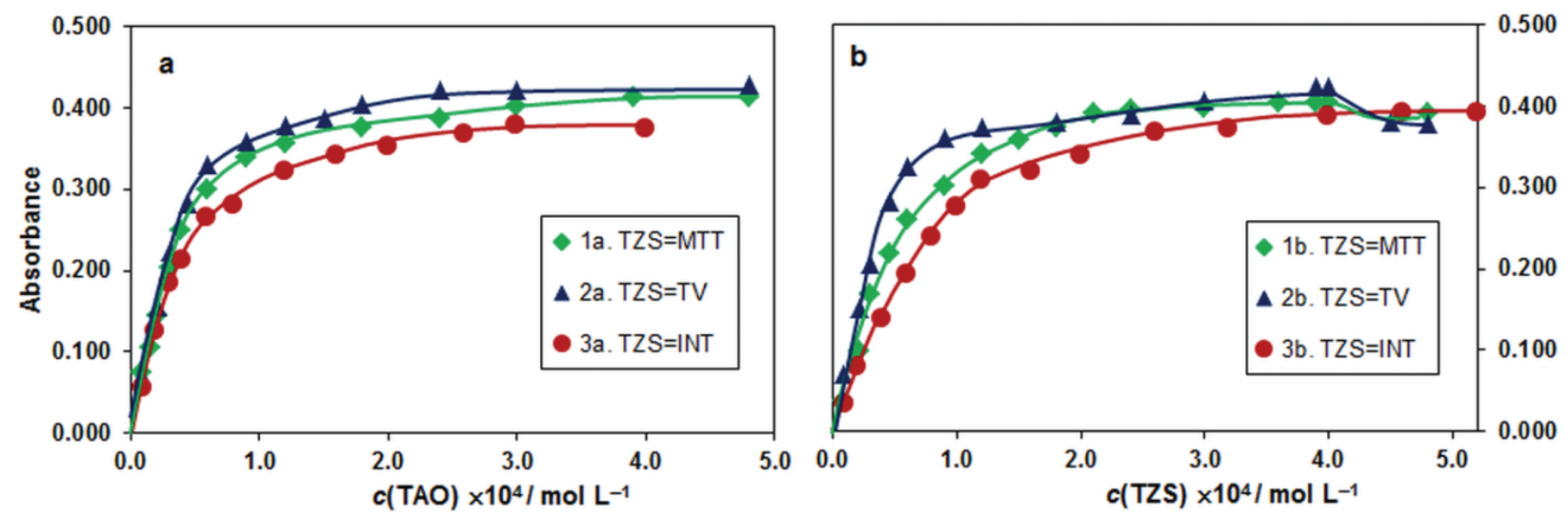

Figure 3. Effect of TAO and TZS concentration on the absorbance of the extracted ternary complexes $\left(c(\mathrm{~V}(\mathrm{~V}))=2.0 \times 10^{-5} \mathrm{~mol}\right.$ $\left.\mathrm{L}^{-1}\right)$ : a) absorbance $v s$. concentration of TAO; b) absorbance $v s$. concentration of TZS. $(1 \mathrm{a}, 1 \mathrm{~b}) \mathrm{pH}=4.9 ;(1 \mathrm{a}) c(\mathrm{MTT})=6.0 \times 10^{-4}$ mol L ${ }^{-1}$, (1b) $c($ TAO $)=4.5 \times 10^{-4} \mathrm{~mol} \mathrm{~L}^{-1} ;(2 \mathrm{a}, 2 \mathrm{~b}) \mathrm{pH}=5.2 ;(2 \mathrm{a}) c(\mathrm{TV})=3.9 \times 10^{-4} \mathrm{~mol} \mathrm{~L}^{-1},(2 \mathrm{~b}) c(\mathrm{TAO})=3.0 \times 10^{-4} \mathrm{~mol} \mathrm{~L}^{-1}$; (3a,3b) $\mathrm{pH}=5.4$; (3a) $c\left(\right.$ INT) $=4.0 \times 10^{-4} \mathrm{~mol} \mathrm{~L}^{-1},(3 \mathrm{~b}) c(\mathrm{TAO})=3.0 \times 10^{-4} \mathrm{~mol} \mathrm{~L}^{-1}$.

accordance with the observed asymmetric trend of the resulting spectral curves 1 and 2 with left slopes steeper than the right ones and maxima located at slightly higher wavelengths ( $545 \mathrm{~nm}>544 \mathrm{~nm})$.

The effect of $\mathrm{pH}$ of the aqueous phase on the absorbance of the extracted ternary complexes is shown in Figure 2. A buffer solution with a concentration of 2 mol L ${ }^{-1}$ was applied to control $\mathrm{pH}$. The use of different volumes of the buffer in the range of $1-3 \mathrm{~mL}$ (per 10 $\mathrm{mL}$ total volume of the aqueous phase) did not exert noticeable influence on the absorbance value. All further experiments were carried out with $2 \mathrm{~mL}$ buffer solutions with $\mathrm{pH}$ in the intervals of 4.9-5.2 (when TZS $=$ MTT and TV) or 5.4-5.5 (when TZS = INT).

The extraction time, the concentration of the reagents TAO and TZS (Figure 3) were other variables

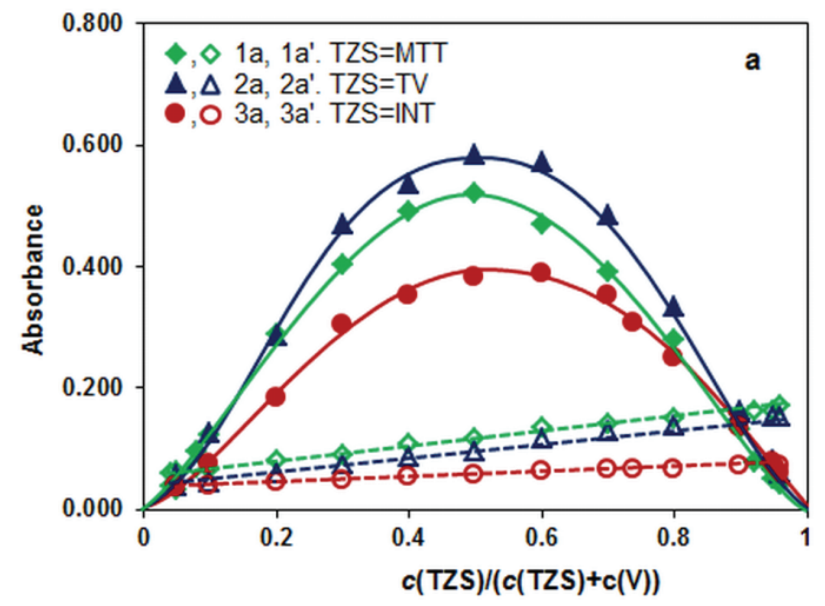

optimized in our study. The established optimum conditions are listed in Table 2.

\section{Composition and General Formula}

The method of continuous variations, ${ }^{29}$ whose applications have been extended to LLE systems ${ }^{30}$ and complexes of the type $\mathrm{A}_{n} \mathrm{~B}_{n}$ (where $\left.n>1\right)$, ${ }^{31}$ was applied to determine the $\mathrm{V}(\mathrm{V})$-to-TZS and $\mathrm{V}(\mathrm{V})$-to-TAO molar ratios in the ternary complexes. The results are presented in Figure 4. One can assume that the absorption maxima are located at a mole fraction of 0.5. However, the trend of the isomolar curves in both cases is not identical when we discuss the possibility of formation of $1: 1: 1$ or higher ternary species $(2: 2: 2,3: 3: 3$, etc.). The concavities, which are visible at the ends of the curves in Figure 4a, are indicative for the formation of com-

Figure 4. Determination of $T Z S / V(V)$ and $T A O / V(V)$ ratios: a) isomolar TZS-V(V) curves $(1 \mathrm{a}, 2 \mathrm{a}, 3 \mathrm{a} ; k=c(\mathrm{TZS})+c(\mathrm{~V}(\mathrm{~V}))=$

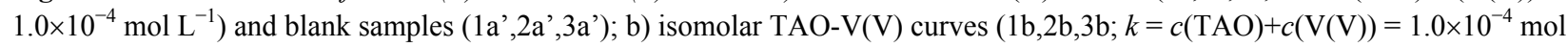
$\left.\mathrm{L}^{-1}\right)$ and blank samples $\left(1 \mathrm{~b}^{\prime}, 2 \mathrm{~b}^{\prime}, 3 \mathrm{~b}^{\prime}\right) .(1 \mathrm{a}, \mathrm{b}) \mathrm{pH}=4.9,(2 \mathrm{a}, \mathrm{b}) \mathrm{pH}=5.2,(3 \mathrm{a}, \mathrm{b}) \mathrm{pH}=5.4 ;$ (1a) $c(\mathrm{TAO})=4.5 \times 10^{-4} \mathrm{~mol} \mathrm{~L}^{-1},(2 \mathrm{a}, 3 \mathrm{a})$ $c(\mathrm{TAO})=3.0 \times 10^{-4} \mathrm{~mol} \mathrm{~L}^{-1} ;(1 \mathrm{~b}, 2 \mathrm{~b}) c(\mathrm{TZS})=3.9 \times 10^{-4} \mathrm{~mol} \mathrm{~L}^{-1} ;(3 \mathrm{~b}) c(\mathrm{INT})=5.0 \times 10^{-4} \mathrm{~mol} \mathrm{~L}^{-1}$. 

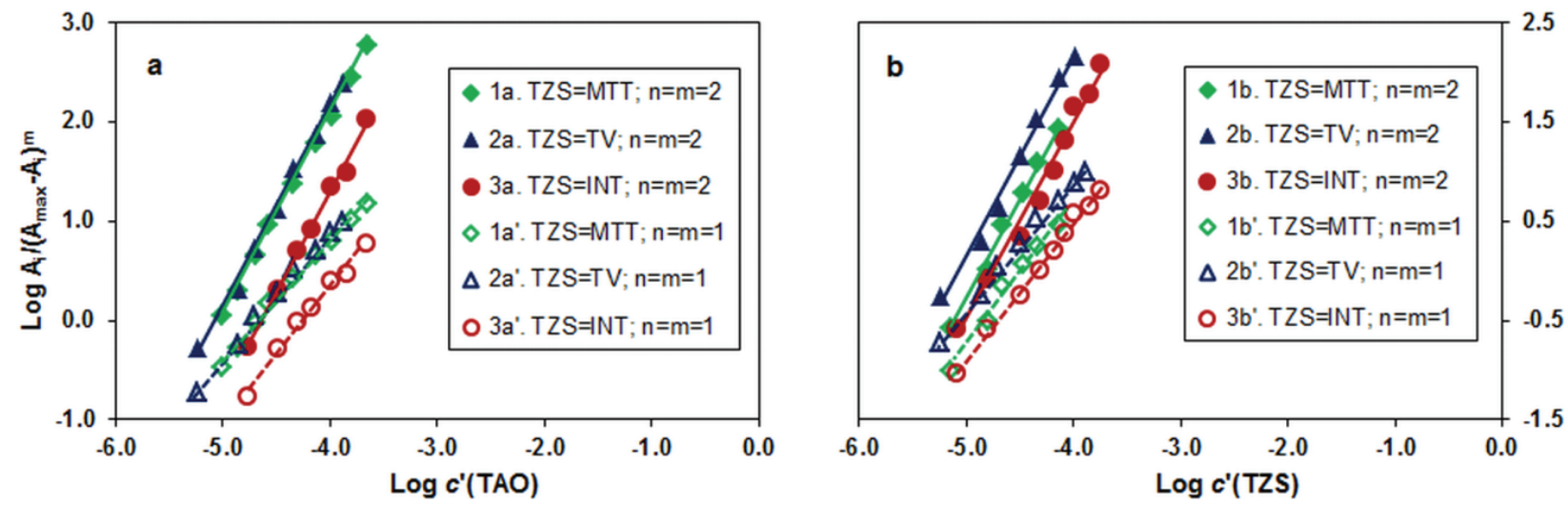

Figure 5. Straight lines obtained by the mobile equilibrium method ${ }^{36}$ for molar ratios of a) TAO to V(V); b) TZS to V(V). Straight lines equations: (1a) $y=2.004 x+10.065 ; R^{2}=0.999$; (1a') $y=1.199 x+5.586 ; R^{2}=0.994$; (2a) $y=2.009 x+10.19 ; R^{2}=$ 0.996; (2a') $y=1.2662 x+5.953 ; R^{2}=0.993$; (3a) $y=2.010 x+9.297 ; R^{2}=0.995 ;$ (3a') $y=1.337 x+5.661 ; R^{2}=0.991$; (1b) $y=$ $2.014 x+9.761 ; R^{2}=0.992 ;\left(1 b^{\prime}\right) y=1.4658 x+6.5669 ; R^{2}=0.984 ;(2 b) y=2.033 x+10.295 ; R^{2}=0.989 ;\left(2 b^{\prime}\right) y=1.309 x+$ $6.148 ; R^{2}=0.993$; (3b) $y=2.004 x+9.461 ; R^{2}=0.983 ;\left(3 \mathrm{~b}\right.$ ') $y=1.376 x+5.950 ; R^{2}=0.995$.

plexes with $2: 2$ or higher [V(V)-TAO]-to-TZS ratio. ${ }^{31}$ On the other hand, the curves presented in Figure $4 \mathrm{~b}$ suggest the formation of simple ternary complexes with a 1:1 V(V)-to-TAO ratio.

The literature survey has shown that the differentiation between 1:1 and 2:2 species by the method of continuous variations ${ }^{31}$ is not always an easy and feasible task. ${ }^{31-35}$ In fact, the concavities are only evident on the curves for complexes of low and medium stability ${ }^{31,33,34}$ at small isomolar concentrations. ${ }^{33}$ Having in mind the ion-association nature of the tetrazolium ternary complexes ${ }^{18}$ we expected higher stability of the $\mathrm{V}^{\mathrm{V}}$-TAO bonds than the bonds between the tetrazolium

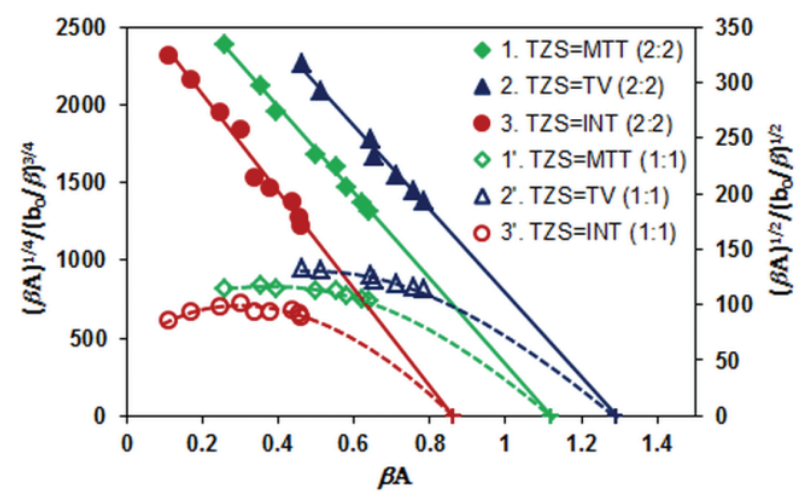

Figure 6. Straight lines (1-3; left ordinate) and curves (1'-3'; right ordinate) obtained by the dilution method $^{37}$ for molar ratios of $\mathrm{TZS}$ to $\mathrm{V}(\mathrm{V}) .\left(1,1^{\prime}\right) c(\mathrm{~V}(\mathrm{~V}))=c(\mathrm{MTT}), c(\mathrm{TAO})=$ $4.5 \times 10^{-4} \mathrm{~mol} \mathrm{~L}^{-1}, \mathrm{pH}=5.1 ;\left(2,2^{\prime}\right) c(\mathrm{~V}(\mathrm{~V}))=c(\mathrm{TV}), c(\mathrm{TAO})$ $=3.0 \times 10^{-4} \mathrm{~mol} \mathrm{~L}^{-1}, \mathrm{pH}=5.4 ;\left(3,3^{\prime}\right) c(\mathrm{~V}(\mathrm{~V}))=c(\mathrm{INT})$, $c(\mathrm{TAO})=4.5 \times 10^{-4} \mathrm{~mol} \mathrm{~L}^{-1}, \mathrm{pH}=5.4$. Straight lines equations: (1) $y=-2753.4 x+3077.5 ; R^{2}=0.996$; (2) $y=-2710.9 x$ $+3491.7 ; R^{2}=0.998 ;$ (3) $y=-3123.2 x+2688 ; R^{2}=0.993$. cation $\left(\mathrm{TZ}^{+}\right)$and the anionic $\mathrm{V}(\mathrm{V})-\mathrm{TAO}$ chelate. From this point of view, the conventional shape (without inflections) of the isomolar curves in Figure 4b (suggesting 1:1 complex formation) was considered misleading.

In order to clear up the composition of the ternary complexes (1:1:1 or 2:2:2) we used two other methods: the mobile equilibrium method ${ }^{36}$ (Figure 5) and the dilution method ${ }^{37}$ (Figure 6). The obtained results are in accordance with the concept that 2:2:2 ternary ionassociation complexes are formed in all three LLE systems.

Having in mind that in most cases $\mathrm{V}(\mathrm{V})$ (in the form of $\left.\mathrm{VO}_{2}^{+}\right)$produces 1:1:1 complexes with azoderivatives of resorcinol (PAR, TAR) and heavy organic cations ${ }^{38-48}$ (tetrazolium complexes with different molar ratios are described in the review ${ }^{18}-$ e.g. $\mathrm{V}(\mathrm{V}): \mathrm{PAR}: \mathrm{TZS}=1: 2: 3$ or $1: 2: 1$ and V(V):TAR:TZS $=$ $1: 2: 3$ ), we assume that the investigated in our study ternary complexes can be regarded as dimers and expressed with the general formula $\left(\mathrm{TZ}^{+}\right)_{2}\left[\mathrm{VO}_{2}\left(\mathrm{TAO}^{2-}\right)\right]_{2}$. The suggested equation of complex formation and extraction, based on information concerning the state of $\mathrm{V}(\mathrm{V})^{49}$ and $\mathrm{TAO}^{50}$ at $\mathrm{pH}_{\mathrm{opt}}$, is as follows:

$$
\begin{aligned}
& 2 \mathrm{H}_{2} \mathrm{VO}_{4}^{-}(\mathrm{aq}) \\
& \quad \Leftrightarrow\left(\mathrm{TZ}_{2} \mathrm{TAO}_{(\mathrm{aq})}+2 \mathrm{TZ}_{2}^{+}\left[\mathrm{VO}_{2}(\mathrm{TAO})\right]_{2(\mathrm{o})}+4 \mathrm{H}_{2} \mathrm{O}_{(\mathrm{aq})}\right.
\end{aligned}
$$

\section{Constants of Extraction and Other Characteristics Concerning the Application of the Complexes}

The dilution method ${ }^{37}$ (Figure 6) also allows calculating the conditional extraction constants of the ternary complexes. The results are shown in Table 3 along with 
Table 3. Calculated values $(P=95 \%)$ of the extraction constants $\left(K_{\mathrm{ex}}\right)$, distribution coefficients $(D)$ and recovery factors $(R \%)$ at the optimum conditions

\begin{tabular}{|c|c|c|c|}
\hline Extraction system & $\log K_{\mathrm{ex}}$ & $\log D^{(\mathrm{e})}$ & $R \%{ }^{(\mathrm{f})}$ \\
\hline $\mathrm{V}(\mathrm{V})$-TAO-MTT- $\mathrm{H}_{2} \mathrm{O}$-chloroform & $\begin{array}{l}13.60 \pm 0.02(N=8)^{(\mathrm{a})} \\
13.54 \pm 0.08(N=4)^{(\mathrm{b})} \\
13.60 \pm 0.07(N=3)^{(\mathrm{c})}\end{array}$ & $1.33 \pm 0.01(N=3)$ & $95.5 \pm 0.09(N=3)$ \\
\hline $\mathrm{V}(\mathrm{V})-\mathrm{TAO}-\mathrm{TV}-\mathrm{H}_{2} \mathrm{O}$-chloroform & $\begin{array}{c}13.76 \pm 0.02(N=7)^{(\mathrm{a})} \\
13.76 \pm 0.06(N=4)^{(\mathrm{b})} \\
13.8 \pm 0.1(N=3)^{(\mathrm{c})}\end{array}$ & $1.67 \pm 0.01(N=4)$ & $97.9 \pm 0.03(N=4)$ \\
\hline $\mathrm{V}(\mathrm{V})$-TAO-INT- $\mathrm{H}_{2} \mathrm{O}$-chloroform & $\begin{array}{c}13.48 \pm 0.02(N=9)^{(\mathrm{a})} \\
13.12 \pm 0.03(N=4)^{(\mathrm{b}, \mathrm{d})} \\
13.52 \pm 0.07(N=3)^{(\mathrm{c})}\end{array}$ & $1.55 \pm 0.01(N=4)$ & $97.3 \pm 0.06(N=4)$ \\
\hline \multicolumn{4}{|c|}{ 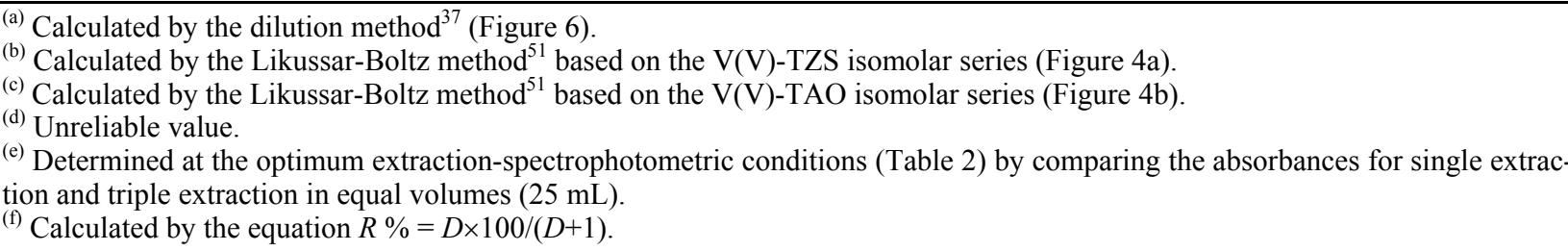 } \\
\hline
\end{tabular}

results obtained by the Likussar-Boltz method ${ }^{51}$ based on the isomolar curves shown in Figure 4 and additional experiments for determining the values of $y_{\max }$. Since the Likussar-Boltz method uses the "normalized absorbance" concept, the validity of Beer's law had to be checked first $^{14}$ for vanadium concentrations up to at least $5 \times 10^{-5}$ mol L ${ }^{-1}\left(2.55 \mu \mathrm{g} \mathrm{mL}^{-1}\right)$. The data included in Table 4 show that there are no obstructions to use the method, connected to the linearity of the $A=f(c(\mathrm{~V}(\mathrm{~V}))$ plots. However, Likussar and Boltz did not consider in their work $^{51}$ the case for 2:2 complexes formation in detail. That is why, we performed our calculations by an equation, $K_{\mathrm{ex}}=0.0625 \times(4 / k)^{3} \times y_{\max } \times\left(1-y_{\max }\right)^{-4}$, which was additionally derived from the mentioned source ${ }^{51}$.
It could be seen from Table 3 that the results for $\log K_{\text {ex }}$ are statistically indistinguishable when TZS is MTT or TV in all three cases of calculation (dilution method, Likussar-Boltz method based on Figure 4a, and Likussar-Boltz method based on Figure 4b). However, the obtained value of the extraction constant for the $\mathrm{V}$ TAO-INT system was lower $\left(\log K_{\mathrm{ex}}=13.12 \pm 0.03\right)$ when the isomolar curve 3 a (Figure 4) was used. An explanation can be the influence of the side reaction, which is responsible for the distortion of straight line $3 b$ in Figure 5 and straight line 3 in Figure 6. In fact, $\left(\mathrm{INT}^{+}\right)_{2}\left[\mathrm{VO}_{2}\left(\mathrm{TAO}^{2-}\right)\right]_{2}$ is more unstable than $\left(\mathrm{MTT}^{+}\right)_{2}\left[\mathrm{VO}_{2}\left(\mathrm{TAO}^{2-}\right)\right]_{2}$ and $\left(\mathrm{TV}^{+}\right)_{2}\left[\mathrm{VO}_{2}\left(\mathrm{TAO}^{2-}\right)\right]_{2}$. The lowest values of the $y$-intercepts for the $2: 2$ straight

Table 4. Characteristics concerning the application of the ternary complexes for LLE-spectrophotometric determination of vanadium

\begin{tabular}{|c|c|c|c|}
\hline Analytical characteristics & $\begin{array}{c}\mathrm{V}(\mathrm{V})-\mathrm{TAO}-\mathrm{MTT}-\mathrm{H}_{2} \mathrm{O}- \\
\mathrm{CHCl}_{3}\end{array}$ & $\begin{array}{l}\mathrm{V}(\mathrm{V})-\mathrm{TAO}-\mathrm{TV}-\mathrm{H}_{2} \mathrm{O}- \\
\mathrm{CHCl}_{3}\end{array}$ & $\begin{array}{c}\mathrm{V}(\mathrm{V})-\mathrm{TAO}-\mathrm{INT}-\mathrm{H}_{2} \mathrm{O}- \\
\mathrm{CHCl}_{3}\end{array}$ \\
\hline Molar absorptivity $(\varepsilon) / \mathrm{L} \mathrm{mol}^{-1} \mathrm{~cm}^{-1}$ & $(2.09 \pm 0.05) \times 10^{4}$ & $(2.14 \pm 0.08) \times 10^{4}$ & $(1.92 \pm 0.03) \times 10^{4}$ \\
\hline Sandell's sensitivity / $\mathrm{ng} \mathrm{cm}^{-2}$ & 2.44 & 2.38 & 2.65 \\
\hline Adherence to Beer's law / $\mu \mathrm{g} \mathrm{mL}^{-1}$ & up to 3.6 & up to 4.1 & up to 4.6 \\
\hline Linear regression equation $y=a x+b$ & $\begin{array}{l}y=0.4202 x-0.0076 \\
\left(R^{2}=0.9991 ; N=15\right)\end{array}$ & $\begin{array}{l}y=0.4413 x-0.0096 \\
\left(R^{2}=0.9992 ; N=14\right)\end{array}$ & $\begin{array}{l}y=0.3791 x+0.0003 \\
\left(R^{2}=0.9996 ; N=13\right)\end{array}$ \\
\hline $\begin{array}{l}\text { Standard deviations of the slope }(a) \\
\text { and } y \text {-intercept }(b)\end{array}$ & $0.0034 ; 0.0058$ & $0.0035 ; 0.0060$ & $0.0021 ; 0.0046$ \\
\hline Limit of detection (LOD) $/ \mu \mathrm{g} \mathrm{mL}^{-1}$ & $0.11^{\text {(a) }}$ & $0.12^{\text {(a) }}$ & $0.09^{(a)}$ \\
\hline Limit of quantitation (LOQ) $/ \mu \mathrm{g} \mathrm{mL}^{-1}$ & $0.36^{(\mathrm{b})}$ & $0.39^{(b)}$ & $0.30^{(\mathrm{b})}$ \\
\hline Standard deviation of the blank & 0.0062 & 0.0080 & 0.0013 \\
\hline Relative standard deviation (RSD) / \% & $1.6^{(\mathrm{c})}$ & $2.3^{(\mathrm{c})}$ & $1.0^{(\mathrm{c})}$ \\
\hline
\end{tabular}


lines in Figure 5 are evidence for the correctness of this statement. It is more reasonable to expect ${ }^{34}$ that other complex species are also present in the solution, along with the principle $2: 2: 2$ complex, when the complexation interaction is weak. In this case, the continuous variation curve loses its symmetric character (see curve 3a, Figure 4); and this inevitably will reflect on the reliability of the results ${ }^{14,52,53}$ obtained by the Likussar-Boltz method.

Table 4 shows that the influence of side reactions on the complex formation with INT can be neglected when the extraction is performed at the optimum conditions. The linear regression equations and the attendant parameters listed in this table (standard deviation of the slopes and $y$-intercepts, standard deviation of the blank samples, LODs, LOQs, and RSDs) show that INT can be recognized as the best TZS for LLEspectrophotometric determination of vanadium. An additional reason to make such a conclusion is the literature, ${ }^{18,25,54}$ which suggests that INT can ensure better selectivity than many other cationic ion-association reagents, including MTT and TV.

\section{CONCLUSION}

The present paper is the first one, which deals with the LLE-spectrophotometric behaviour of TAO. It was found that $V(V)$ forms colored and well chloroformextractable ternary complexes with this reagent and TZS (INT, TV and INT). Generally speaking, the extraction efficiency of these complexes is higher than those for the V(V)-TAR-TZS complexes ${ }^{24}$ and their composition is different $-2: 2: 2$. They can be regarded as dimers $\{2 \times(1: 1: 1)\}$ with a general formula expressing their ionassociation character: $\left(\mathrm{TZ}^{+}\right)_{2}\left[\mathrm{VO}_{2}\left(\mathrm{TAO}^{2-}\right)\right]_{2}$. $\mathrm{TV}^{+}$, as a component of the ternary complex, can ensure the highest extractability $\left(\log K_{\mathrm{ex}}=13.76 ; R=97.9 \%\right.$ ) and molar absorptivity $\left(\varepsilon_{545}=2.14 \times 10^{4} \mathrm{~L} \mathrm{~mol}^{-1} \mathrm{~cm}^{-1}\right)$. However, INT can be recognized as the best reagent for extraction-spectrophotometric determination of $\mathrm{V}(\mathrm{V})$ due to the lowest limits of detection and quantitation, the lowest absorption of the blank, the widest dynamic range, and the highest reproducibility of the results achieved with this reagent.

Acknowledgements. The authors would like to thank the Research Fund of the University of Plovdiv "Paissii Hilendarski" for its financial support (contract NI-13-HF006)

\section{REFERENCES}

1. B. S. Jensen, Acta Chem. Scand. 14 (1960) 927-932.

2. G. G. Shalamova, Tr. Perm. Med. Inst. 108 (1972) 48-53.

3. N. N. Kiryakhina, Tr. Perm. Med. Inst. 108 (1972) 178-181

4. K. Ueda, Y. Kiyota, and Y. Yamamoto, Bull. Chem. Soc. Jpn. 54 (1981) 3763-3767.
5. H. R. Hovind, Analyst 100 (1975) 769-796.

6. S. Oszwaldowski and M. Jarosz, Chem. Anal. (Warsaw) 42 (1997) 739-756

7. V. A. Lemos, E. S. Santos, M. S. Santos, and R. T. Yamaki, Microchim. Acta 158 (2007) 189-204.

8. Y. Chung and W. Chung, Bull. Korean Chem. Soc. 24 (2003) 1781-1784.

9. S. A. Rocha, Desenvolvimento de sistemas de separação e préconcentração para determinação de metalis em águals naturalis, $\mathrm{PhD}$ thesis, Universidade Federal Da Bahia, Salvador, Brazil, 2005.

10. S. A. Rocha and S. L. Ferreira, Eurasian J. Anal. Chem. 2 (2007) $1-11$.

11. M. Soylak and M. Tuzen, J. Hazard. Mat. 152 (2008) 656-661.

12. M. Tuzen, M. Soylak, D. Citak, H. S. Ferreira, M. G. A. Korn, and M. A. Bezerra, J. Hazard. Mat. 162 (2009) 1041-1045.

13. W. N. L. dos Santos, D. D. Cavalcante, H. S. Ferreira, C. F. das Virgens, A. R. Borges, M. M. Silva, and M. G. R. Vale, Int. J. Environ. Anal. Chem. 91 (2011) 1447-1452.

14. K. B. Gavazov, Chemistry 22 (2013) 222-253.

15. F. I. Lobanov, G. K. Nurtaeva, and E. E. Ergozhin, Ekstraktsiya kompleksov ionov metallov s piridinovymi oksiazosoedineniyami, Nauka, Alma-Ata, 1983.

16. T. Ying, Z. J. Li, Z. Juan, and J. M. Pan, Rev. Anal. Chem. 24 (2005) 103-147.

17. W. Lee, M.-K. Kim, E.-K. Kim, K.-S. Park, and Y.-S. Kim, Microchem. J. 70 (2001)187-194.

18. K. B. Gavazov, V. D. Lekova, and A. N. Dimitrov, Russ. Chem Rev. 76 (2007) 169-179.

19. M. Boggs, L. Gribat, C. Boele, and N. Wall, J. Radioanal. Nucl. Chem. 293 (2012) 843-846.

20. L. Dospatliev, N. V.Georgieva, A.I. Pavlov, and Z. Yaneva, Trakia J. Sci. 8 (2010)16-19.

21. D. Kostova, J. Int. Sci. Publ. Ecol. Saf. 4 (2010) 170-177.

22. V. Pitschmann, Z. Kobliha, and I. Tušarová, Adv. Milit. Technol. 6 (2011) 19-27.

23. D. Kostova, J. Anal. Chem. 66 (2011) 384-388.

24. K. B. Gavazov, V. D. Lekova, A. N. Dimitrov, and G. I. Patronov, Cent. Eur. J. Chem. 5 (2007) 257-270.

25. K. Gavazov, Z. Simeonova, and A. Alexandrov, Talanta 52 (2000) 539-544.

26. K. Gavazov, V. D. Lekova, G. I. Patronov, and M. Turkyilmaz, Chem. Anal. (Warsaw) 51 (2006) 221-227.

27. K. B. Gavazov, V. D. Lekova, and G. I. Patronov, Acta Chim. Slov. 53 (2006) 506-511.

28. K. B. Gavazov and G. K. Toncheva, J. Adv. Chem. 5 (2013) 641-651.

29. P. Job, Ann. Chim. (Paris) 9 (1928) 113-134

30. H. Irving and T. B. Pierce, J. Chem. Soc. (1959) 2565-2574.

31. K. S. Klausen and F. J. Langmyhr, Anal. Chim. Acta 28 (1963) 335-340.

32. W. A. E. McBryde, Talanta 21 (1974) 979-1004.

33. L. Sommer and M. Langová, C R C Critical Rev. Anal.Chem. 19 (1988) 225-269.

34. A. Sayago, M. Boccio, and A. G. Asuero, Int. J. Pharm. 295 (2005) 29-34.

35. E. J. Olson and P. Bühlmann, J. Org.Chem. 76 (2011) 8406-8412.

36. Z. Zhiming, M. Dongsten, and Y. Cunxiao, J. Rare Earths 15 (1997) 216-219.

37. T. R. Galan, A. A. Ramirez, and M. R. Ceba, Talanta 27 (1980) 545-547.

38. Z. Simeonova, K. Gavazov, and A. Alexandrov, Russ. J. Inorg. Chem, 44 (1999) 621-625.

39. L. Marić, M. Široki, Z. Štefanac, and M. J. Herak, Microchem. J. 24 (1979) 536-544.

40. E. Papp and J. Inczédy, Talanta 27 (1980) 49-51. 
41. E. Grzegrzolka, Chem. Anal. (Warsaw) 20 (1975) 347-352.

42. A. K. Babko, A. I. Volkova, and T. E. Get'man, Zh. Neorg. Khim. 11 (1966) 374-380.

43. R. M. Pogranichnaya, B. E. Reznik, V. V. Nerubashchenko, A. G. Zezyanova, and A. V. Tsevina, Zh. Anal. Khim. 30 (1975) 180-182.

44. A. Yerramilli, C. S. Kavipurapu, R. R. Manda, and C. M. Pillutha, Anal. Chem. 58 (1986) 1451-1453.

45. N. Galesic and M. Siroki, Acta Crystallogr. B 35 (1979) 2931-2937.

46. M. Široki and C. Djordjević, Z. Anorg. Allg. Chem. 430 (1977) 277-282.

47. N. Galesic and M. Siroki, Acta Crystallogr. C 40 (1984) 378-381.
48. M. Široki, L. Marić, and Z. Štefanac, J. Inorg. Nucl. Chem. 43 (1981) 1151-1153.

49. M. J. C. Taylor and J. F. Staden, Analyst 119 (1994) 1263-1276.

50. N. Menek, E. Eren, and S. Topçu, Dyes Pigments 68 (2006) 205-210.

51. W. Likussar and D. F. Boltz, Anal. Chem. 43 (1971) 1265-1272.

52. F. Woldbye, Acta Chem. Scand. 9 (1955) 299-309.

53. V. M. S. Gil and N. C. Oliveira, J. Chem. Edu. 67 (1990) 473-478.

54. Z. Simeonova, K. Gavazov, and A. Alexandrov, Cent. Eur. J Chem. 4 (2006) 258-266.

55. A. Shrivastava and V. B. Gupta, Chron. Young Sci. 2 (2011) $21-25$. 